\section{Kastamonu Eğitim Dergisi Kastamonu Education Journal}

Mart 2019 Cilt:27 Sayı:2

kefdergi.kastamonu.edu.tr
Başvuru Tarihi/Received: 14.02.2018

Kabul Tarihi/Accepted: 13.06.2018

DOI: 10.24106/kefdergi.2691

\title{
Şiddet Davranışları Olan Çocuklara Sahip Ebeveynlere Yönelik Şiddetsiz Karşı Koyma Programının Etkisi ${ }^{1}$
}

\section{The Effect of the Non-violent Resistance Program for the Parents of Children with Violent Behaviors}

\section{Öz}

\author{
Suat KILIÇARSLAN ${ }^{2}$
}

\begin{abstract}
"Şiddetsiz Karşı Koyma" programı, şiddet ve saldırganlık içeren davranışları olan çocuk ve ergenlere sahip ebeveynler, öğretmenler ve bakım veren kişiler için geliştirilmiştir. Ebeveynlerin çocuklarıyla karşılıklı olarak gerilimi tırmandıran etkileşimleri ile etkili bir biçimde baş etmeleri için yardımcı olmayı amaçlayan yeni bir eğitim modelidir. Bu araştırmanın amacı, şiddet davranışları olan çocuklara sahip ebeveynlere yönelik uygulanan "Şiddetsiz Karşı Koyma" ebeveyn programının çocuklarda görülen şiddet ve saldırganlık davranışları, ebeveynlerin yaşadıkları stres, algıladıkları yetersizlik duyguları ve hissettikleri destek düzeyleri üzerindeki etkisini incelemektir. Araştırmanın verileri deney ve kontrol grubunda bulunan ebeveynlere uygulanan 'Aile Değerlendirme Ölçeği' Anne Baba Stres Ölçeği', ve 'Öznel Rahatsızık Birimleri Anketi' aracılığıyla elde edilmiştir. Söz konusu ölçekler deney ve kontrol grubu ebeveynlerine öntest, sontest ve izleme ölçümleri olarak uygulanmıştır. Bulgular incelendiğinde, ebeveynlere uygulanan programların aile içi ilişkilerde değişiklikler meydana getirdiği, çocuklarda görülen şiddet ve saldırganlık içeren davranışları azalttğı, ebeveynlerin stres ve yetersizlik duygularını anlamlı derecede düşürdüğü ve algıladıkları destek düzeylerini ise artırdığı görülmüştür. Bu sonuçlardan hareketle eğitim öğretim ortamlarında ve çocuk ve ergenlere yönelik hizmet veren diğer kurumlarda, şiddetsiz karşı koyma programının anne-babalarla işbirliği çerçevesinde uygulanması önerilmektedir.
\end{abstract}

Anahtar Kelimeler: Aile ilişkileri, destek, ebeveyn yetersizliği, saldırganlık, şiddet, şiddetsiz karşı koyma ebeveyn programı

\section{Abstract}

The "Non-violent Resistance" program was developed for parents, teachers and caregivers who have children and adolescents exhibiting aggressive and violent behaviors. It is a new educational model aiming to help parents cope effectively with their mutual interactions with their children that increase tension. The aim of this research is to examine the effect of the "Non-violent Resistance Program", which is a program for parents with children with violent behaviors, on the violent and aggressive behaviors seen in children, and the levels of the stress experienced by parents, the feelings of perceived inadequacy and support they feel. The data of the study were obtained through the 'Family Evaluation Scale', 'Parenting Stress Index' and 'Questionnaire of Subjective Disturbance Units', all of which were administered to the parents in the experimental and control groups. These aforementioned scales were administered to the parents of the experimental and control groups as pretest, posttest and follow-up measurements. When the findings were examined, it was seen that the programs administered to parents created changes in family relationships, reduced the violence and aggressive behaviors seen in children, significantly decreased parents' feelings of stress and inadequacy and increased their levels of perceived support. Based on these results, it is suggested that the Non-Violent Resistance Program should be implemented in educational environments and other institutions providing services for children and adolescents with cooperation from parents.

Keywords: Aggression, family relationships, nonviolent resistance parental program, parental inactivity, support, violence

1. Bu çalışma, 18 - 21 Ekim 2017 tarihleri arasında Anatalya'da düzenlenen 'International INES Academic Researches Congress'te (INES 2017) özet sözlü bildiri olarak sunulmuştur.

2. Niğde Ömer Halisdemir Üniversitesi, Eğitim Fakültesi, Niğde, Türkiye; https://orcid.org/0000-0002-2907-8480

Atff / Citation: Kılıçarslan, S. (2019). Şiddet davranışları olan çocuklara sahip ebeveynlere yönelik şiddetsiz karşı koyma programının etkisi.Kastamonu Education Journal, 27(2), 701-716. doi:10.24106/kefdergi.2691 


\section{Extended Summary}

There has been an increase in violent and aggressive behaviours in Turkey and in the world in recent years. These kinds of unwanted behaviours encountered in childhood or adolescence might have various reasons. When rooted problems such as violence and aggression are examined, it is important to investigate genetic, biological and psychological factors as well as negative communication patterns and the effects of the psycho-cultural structure of the society one lives in. In this process, this spiral is broken mainly by regulating communication patterns between parents and adolescents in a healthy way and helping parents to gain some skills.

Non-Violent Resistance (NVR) is a new coping model which aims to help parents to effectively cope with feelings of hopelessness, loneliness and conflicts caused by interaction types increasing tension. NVR parent education was mainly designed for parents in order to help them to cope with their children's violent, self-destructive activities, skipping school and other acute discipline problems.

Family life has become much more complicated today due to various factors such as immigration, urbanization, developments in technology, and industrialization. Children who do not grow up in a healthy family environment and with a healthy interaction pattern might demonstrate violent and destructive behaviours when they face difficulties. The purpose of this study is to investigate the effects of Non-Violent Resistance parent education program applied to parents who have children attending primary school and demonstrating violent behaviours on children's violent behaviours and family interaction The purpose of NVR program is primarily to help parents who experience inadequacy and helplessness and experience anxiety about the problems related to their children by teaching them how to resist their children's violent and self-destructive behaviours effectively, without provoking or giving up and to make them regain their parenting. Although the intervention program is conducted with parents, the main point of view for violence problem is handled in a cyclic framework, and it focuses on both parents and children.

This study utilized pre-test post test control group (PPCG) quasi-experimental design, which is one of the experimental research designs. Participants of the study were parents of children who demonstrated problems about violent and aggressive behaviours at school in the 2016-2017 education year, in a primary school in Niğde. 16 volunteer parents were chosen among parents of children who were guided to Psychological Counselling Unit by their classroom teachers or school management due to their unwanted, violent behaviours; the parents were then assigned to experimental and control groups (8 experimental group, 8 control group). The experimental group, which was formed with parents of children who demonstrated violent and aggressive behaviours, was applied "Non-Violent Resistance" parent program. Data were collected through "Family Assessment Scale", "Parent Stress Scale" and "Subjective Disturbance Units Questionnaire" in relation to perceptions about parent inadequacy, violence, and support. The scales were administered to the parents in the experimental and control groups as pretest, posttest and monitoring measurements. Analysis of the data was performed using SPSS 22 package programming.

An analysis of the results indicates that the program had significant effects on the family assessment total score and subscales including Problem solving, Communication, Roles, Giving Emotional Reactions, Showing the Required Interest, Behaviour Control, and General Functions. On the other hand, there was a significant decrease in parents' stress levels and children's violent behaviours attitudes and behaviours and feelings of inadequacy, and there was an increase in the amount of support they felt.

Violence and aggressiveness in this study are handled not only as a problem experienced by an individual but as a social and cultural structure problem which involves family and family relationships and interaction styles. Results show that in comparison to the parents in the control group, the parents in the experimental group who were administered Non-Violent resistance program demonstrated improvement in family interactions, decreased violent behaviours and positive effects on feelings of inadequacy, and stress and perceptions of support. Results of the study are parallel with other similar experimental studies conducted in Turkey.

NVR model, which was developed with a view to decreasing violent and aggressive behaviours of children and adolescents by targeting to repair familial relationships and interaction types, has not been implemented much in Turkey yet. Particularly these kinds of support programs help parents who have children demonstrating violent behaviours to cope with feelings of helplessness, inadequacy and loneliness, to increase parental and familial interaction skills, and to cope with the conflicts between parents and children in a more constructive way. Programs that aim to prevent and interfere violent and aggressive behaviours in children and adolescents are quite limited in number in Turkey. More studies are needed in order to identify the effectiveness of NVR model, which involves all family members by using systemic therapy as a base and considering family structures and cultural views as well.

Besides, the program is believed to contribute to parents and psychological counsellors and educators in the school environment to cope with aggressive behaviours among children and adolescents. In this regard, NVR education program for parents who have children with violent and aggressive behaviours is considered to be beneficial for parents and educators in school environments and other institutions. 


\section{Giriş}

Türkiye'de ve dünyada aile içinde ve okullarda çocukların göstermiş olduğu saldırganlık ve şiddet içeren davranışlarda son yıllarda önemli düzeyde artş görülmektedir. Şiddet, başkalarına gözdağı verme, kendine ya da malına zarar verme, fiziksel yaralamaya sebep olma niyeti ile fiziksel güç kullanımı ya da tehdit durumudur (D’Andrea, 2004). Dünya Sağlık Örgütü (DSÖ) şiddeti, "bireyin kendisine, diğer bir kişiye ya da grup veya topluluğa yaralanma, ölüm, psikolojik zarar, yoksunluk ya da gelişim bozukluğuna yol açacak ya da yol açma olasılığı yüksek olacak şekilde, kasıtlı olarak fiziksel güç ya da kudret uygulaması ya da bununla tehdit etmesi" olarak tanımlamaktadır (DSÖ, 2002).

Şiddete ilişkin tanımların ortak yanları incelendiğinde, kaba kuvvet, fiziksel gücün kötü amaçla kullanımı ve şiddet uygulanan kişi veya kişilerin zarara uğratıması dikkat çeken noktalardır (Haskan ve Yıldırım, 2012). Bu çalışmada ele alınan şiddet kavramı, çocukların birbirlerine, kardeşlerine ya da ebeveynlerine okul ya da aile ortamında kaba kuvvet içeren davranışlar ve fiziksel güç kullanmaları anlamı ile kullanılmıştır. Günümüzde şiddet olayları, savaşlar, göç, şehirleşme, teknoloji ve sanayileşme gibi pek çok etken aile yaşamını karmaşık hale getirmektedir. Sağlıklı aile ilişkileri ve etkileşim ağı içerisinde yetişemeyen çocuklar, zorluklarla karşılaştğında aile ve okul ortamlarında şiddet ve yıkıcı davranışlar sergileyebilmektedir.

Kitzmann, Gaylort, Holt ve Kenny (2003) aile içinde şiddete tanık olan çocukların, tanık olmayanlardan daha fazla olumsuz davranışlar sergilediklerini gözlemlemişlerdir. Çocukların ve gençlerin şiddet içeren saldırgan davranışlara yönelik erken yaşam deneyimleri, yetişkinlik yıllarında şiddetin uygulayıcı olmaları riskini artırmaktadır; örneğin, davranış bozukluğu olan gençlerin \% 40-50 si daha sonraki yaşamında antisosyal kişilik bozukluğu geliştirme riski altında olabilmektedirler (Amerikan Çocuk Akademisi ve Ergen Psikiyatrisi, 1997). Ayrıca ailenin sosyal açıdan izole olması ve sosyal destek yoksunluğu da şiddet eğilimi için risk faktörü olarak belirtilmektedir (Heitmeyer ve Hagan, 2005).

Çocukluk ve ergenlik döneminde ortaya çıkan şiddet davranışları; doğuştan sahip olunan bazı olumsuz biyolojik faktörlerle birlikte, ailelerde işsizlik, yoksulluk, düşük eğitim seviyesi, eşler arası çatışmalar ve boşanma, zorlayıcı ebeveynlik rolleri, stres ve aile içindeki olumsuz iletişim örüntüleri ile ilişkilendirilmektedir (Özmen, 2004; Baltacl, 2011). Psikoterapi uygulayıcılarının çocuk ve ergen ruh sağlığında yapmış oldukları klinik uygulama deneyimleri, çocuk ve ergenlerin ebeveynlerine karşı olan saldırgan davranışlarııın da toplumda bir endişe haline geldiğini öne sürmektedir (Cogan, 2014). Davranış sorunları olan çocukların ebeveynleri ile olan iletişimlerine yönelik çalışmalar bu sürecin oldukça problemli olduğunu göstermektedir (Polowczyk ve diğerlerii 2000). Bireylerde görülen saldırgan davranışların nedenleri arasında; ailenin etkileri, özellikle de çocuk yetiştirme tutumlarının payı büyüktür. Aile içerisindeki çatışma ve tartışmalar, karı-koca anlaşmazlıkları ve kavgaları çocuklar üzerinde çok derin ve silinmesi güç izler bırakabilmektedir (Karataş, 2005).

Saldırgan veya diğer şiddet içeren davranış bozukluklarına sahip çocukların tedavisi, genellikle ebeveynler desteklenerek onlarla birlikte yapılmaktadır (Kotchick, Shaffer, Dorsey ve Forehand, 2004). Ebeveyn eğitimi programlarının etkililiği, bu stratejiyi desteklemektedir (Brestan ve Eyberg, 1998). Bu nedenle de çocuklardaki davranış problemlerini önlemek için oluşturulan programlarda aile temel olarak alınmaktadır. Bu programların, ailede var olan yıkıcı faktörleri azaltması ve bunların yerine, etkili, yapıcı ve koruyucu faktörleri koyması büyük önem taşımaktadır (Sanders, 2000).

Şiddetsiz karşı koyma modeli (Non Violent Resistance-NVR), şiddet ve kendine zarar verici davranışlarla baş etmek için gerginliği tırmandırmayan ve kesinlikle şiddet içermeyen yöntemlerle ebeveynlere, öğretmenlere ve diğer bakım veren kişilere yardımcı olmak için oluşturulmuş yeni ve sistematik bir yaklaşımdır (Omer, 2001, 2004). NVR, ebe-veynlerin umutsuzluk, yalnızlık ve çocuklarıyla karşılıklı olarak gerilimi arttıran etkileşimleri ile etkili biçimde başa çıkmaları için yardımcı olmayı hedefleyen yeni bir yaklaşımdır (Weinblatt ve Omer, 2008).

NVR programının hedefi, öncelikle ebeveyn olarak çocuklarının istenmeyen davranışları ile baş etmede yetersizlik yaşayan ve çocuklarıyla ilgili problemlerde gerginliğe kapılan anne-babalara yardım etmek, geri kışkırtma ya da pes etmeksizin çocuğun saldırgan ve kendine zarar verici davranışlarına etkili bir şekilde karşı koymayı öğrenerek onlara ebeveynliklerini geri kazandırmaktır. Müdahale programı, ebeveynlerle yürütülmesine rağmen, temel bakış açısı hem ebeveynler hem de çocuk üzerine yoğunlaşmaktadır (Omer, Steinmetz, Carthy ve Schlippe, 2013).

NVR, açık bir bir mücadele dilidir, fakat bu mücadele kesinlikle şiddet içermemelidir. NVR felsefesi, mücadele ilkesinden vazgeçen kişi veya grupların eninde sonunda şiddetin sürdürülmesine katkıda bulunduğunu varsaymaktadır. Şiddetsiz bir biçimde direnç gösteren kişi her tür fiziksel ve sözlü saldırıdan kaçınmayı ve amacı küçük düşürmek ve aşağılamak olan eylem ve ifadelerden sakınmayı öğrenmelidir. Bu yüzden ebeveynlerin çocukların yıkıcı davranışlarına karşı mücadelesi hakkında açıkça konuşulur. Bu mücadelede, ebeveynler kendilerini tamamen şiddetsiz ve aşağılayıcı 
olmayan bir duruşa adarlar ve karşılıklı olarak gerginliğin tırmanması sürecinde kendilerinin katkılarını kabul ederler. Tipik bir güç mücadeledesinin aksine, ebeveynlerin amacı kendilerini ve çocuklarını (hem şiddet uygulayan hem de şiddete maruz kalanı) korurken aynı zamanda çocuğun yıkıcı davranışlarına karşı koymaktır. Ebeveynler, ilişkideki olumlu elementleri de koruyup geliştirirken, bununla birlikte çocuğun şiddetiyle mücadele ederler. Bu özelliklere bakarak NVR "yıkııı" değil "yapıcı bir mücadele" olarak düşünülmektedir (Alon ve Omer, 2006).

Ebeveynler çocuğun olumsuz davranışlarına karşı koymayı öğrenirken, aynı zamanda kendi tepkilerini kontrol etmeyi de öğrenirler ve böylece gerginlik artışına karşı durma becerilerini geliştirirler. Çocuğun davranışı önemli bir değişkendir, ancak merkezde olan bu değildir. Bu açııdan NVR, kontrol etmektense şiddetsiz bir biçimde mücadele etmeye adanmayı ve kabul etmeyi vurgulamaktadır (Alon ve Omer, 2006; Hayes, Strosahl ve Wilson, 1999; Linehan, 1993).

Saldırganlık içeren yıkıcı davranışları olan çocuk ve ergenlere sahip ebeveynler, çocuklarının alacağı beceri eğitimlerinin yanı sıra kendileri de katılacakları eğitim ve destek programlarından yararlanabilir ve aile içi etkileşimlerinde olumlu yönde değişiklikler sağlayabilirler. Sistemik psikoterapi yaklaşımına dayalı olarak geliştirilen "Şiddetsiz Karşı Koyma Modeli"nde şiddet ve saldırganlık, sadece bir birey sorunu olarak değil, aynı zamanda bir aile ve ailenin de içinde bulunduğu toplumsal ve kültürel bir yapı sorunu olarak ele alınmaktadır. Sistemik psikoterapi yaklaşımına göre, bir bireyin davranışları her şeyden önce içinde bulunduğu aile bağlamı içerisinde ele alınabilir ve anlaşılabilir. Ailenin her bir üyesinin davranışları karşııkılı olarak diğer üyeleri de etkilemektedir (Corey, 2005). Bir aile üyesinin bireysel açıdan sorunlu ve semptomatik davranışı, bireysel dinamiklerin sonucu olarak değil, aile etkileşiminin sonucu olarak ele alınmaktadır (Worden, 2012).

Alanyazın incelendiğinde dünyada ve Türkiye'de ailelere yönelik pek çok farklı aile eğitimi programı uygulandığı görülmektedir. Uygulanan aile eğitim programlarının neticesinde; anne-babaların ebeveynlik becerilerinin arttğı, kendilerini anne-baba olarak daha yeterli hissettikleri, stres düzeylerinin azaldığı, anne-baba-çocuk ilişkilerinin olumlu yönde geliş̧me gösterdiği, ev ortamında gerginliğin azaldığı, aile içi iletişim ve ilişkilerin pozitif yönde farkılaşdığı görülmüştür (Omer, Schorr-Sapir ve Weinblatt, 2008; Weinblatt ve Omer, 2008; Newman, Fagan ve Webb, 2014; Lavi-Levavi, Shachar ve Omer, 2013; Çekiç, 2015; Epli-Koç, 2013; Kaymak-Özmen, 2013; Kabasakal, 2013; Onaylı ve Erdur-Baker, 2013; Kocayürek ve Sümer, 2009; Akgün, 2008. Şahin ve Kalburan (2009) yurt dışında uygulanan farklı aile eğitimlerinin etkililiğini inceledikleri meta analitik çalışmasında, uygulanan programların sonunda ebeveynlerin anne-babalık davranışlarının olumlu yönde değiştiği; ebevynlikle ilgili stres düzeylerinin düştüğü ve özyeterlilik duygularının yükseldiğini belirlemiştir.

Diğer aile eğitim modellerinden farklı olarak ve sistemik aile terapisi yaklaşımına dayalı olarak bütüncül bir bakış açısıyla geliştirilen NVR Modeli'nin uygulandığı çalışmalar Türkiye'de çok sınırlı sayıda olmakla birlikte, yurt dışında pek çok farklı kültürde ve popülasyonla uygulamalar yapılmıştır. Yurt dışında yapılan çalışmalar incelendiğinde; programın ebeveyn ve çocuk arasındaki gerginliği azaltth̆̆ı ve mağdur olan kardeşlere koruma sağladığı (Omer, Schorr-Sapir ve Weinblatt, 2008), ebeveynlerdeki izolasyon, çaresizlik ve gerginliği artıııı davranışların azaldığı, algılanmış sosyal desteğin arttğı ve gençlerin dışa vuran şiddet davranışlarında anlamlı düzeyde azalma olduğu (Weinblatt ve Omer, 2008), aile içinde gerginliğin azaldığı ve koşulsuz sevgi eylemlerinin arttğı (Newman, Fagan ve Webb, 2014), ebeveynlerin çaresizlik duygularının azaldığı, ebeveyn-çocuk gerginlik tırmanması, güç mücadeleleri ve ebeveynsel boyun eğmede pozitif yönde iyileşmeler görüldüğü (Lavi-Levavi, Shachar ve Ömer, 2013), çocukların şiddet içeren davranışlarında ve ebeveynlerin başa çıkma becerilerinde anlamlı düzeyde gelişmeler görüldüğü (Oleffs ve diğerleri, 2009), ebeveynlerin çaresizlik duygularında ve gençlerle yapılan güç mücadelelerinde belirgin azalmalar olduğu (Lavi-Levavi ve diğerleri, 2013), ebeveynlerin çocuklarını daha fazla gözleyebildiği ve sosyal destek kullanımının daha fazla arttğı (Van Holen ve diğerleri, 2015) görülmüştür.

NVR yaklaşımı, okulların yanı sıra, psikotik bozukluk tanısı almış çocuk veya ergenler için yatan psikiyatrik hasta üniteleri gibi diğer kurumsal düzenlemelerde de başarıyla uygulanmaktadır (Goddard, Van Gink, Van der Stegen, Van Driel ve Cohen, 2009). Türkiye'de ise NVR programının etkililiğini sınayan sadece bir deneysel çalışma bulunmaktadır. Kılıçarslan (2016) tarafindan yapılmış bu çalışmada saldırganlık problemi olan ergenlere yönelik sistemik psikoterapi yaklaşımına dayalı hazırlanmış şiddet ve saldırganlıkla baş etme programı ve bu gençlerin ebeveynlerine yönelik de NVR programı uygulanmıştır. Bulgular incelendiğinde, ergenler ve onların anne babalarına uygulanan programların ergenlerde görülen saldırgan davranışları azalttğı, ana-babalarının ebeveynlik becerilerini ve aile ilişkilerini geliştirdiği ve anne-baba stres düzeylerini anlamlı derecede düşürdüğü görülmüştür.

Özetle, saldırgan ve şiddet içeren davranışlar, ülkemiz için önemli toplumsal problemlerdendir. Bu sorunun erken ve en etkili biçimde çözülebilmesi için etkili müdahale çalışmalarına ihtiyaç duyulmaktadır. Bu bağlamda çocuk ve ergenlere yönelik okul temelli önleme programlarının yanı sıra, şiddet ve saldırganlık içeren davranışlara sahip çocukları olan 
anne-babaların aile içi etkileşim becerilerinin geliştirilmesine yönelik psikoeğitim destek programlarının çok önemli olduğu düşünülmektedir. Ülkemizde çocuklarda görülen şiddet içeren davranışları önleme ve müdahaleye yönelik okullarda uygulanan programlar olmakla birlikte, bu davranışların ortaya çıkmasını önlemek açısından aile etkileşimi ve fonksiyonelliğini iyileştirmeye yönelik çalışmalara ihtiyaç olduğu düşünülmektedir.

\section{Araştırmanın Amacı}

Bu araştırmanın amacı, yıkıcı davranışları olan çocuk ve ergenlere sahip ebeveynlere yönelik geliştirilmiş olan 'Şiddetsiz Karşı Koyma' ebeveyn programının, çocuklarda görülen saldırganlık içeren tutum ve davranışlarının azaltılması, aile ilişkilerinin geliştirilmesi, ebeveynlerin yaşadıkları stres ve yetersizlik duygularının azaltılması ve ebeveynlerin çocuklarda görülen şiddet problemleri ile baş etmede hissettikleri destek miktarını artırması üzerindeki etkisini incelemektir. Araştırmada, probleme dayalı olarak NVR programının etkililiğine ilişkin geliştirilen denenceler aşağıda yer almaktadır.

Denence 1: 'Şiddetsiz Karşı Koyma' programının uygulandığı deney grubu ebeveynlerinin kontrol grubu ebeveynlerine göre 'Aile Değerlendirme Ölçeği' toplam puanı ve alt ölçeklerinden (Problem Çözme, Iletişim, Roller, Duygusal Tepki Verebilme, Gereken Ilgiyi Gösterme, Davranış Kontrolü ve Genel Işlevler) aldıkları son-test puanları ön-test puanlarından anlamlı düzeyde düşüktür ve bu fark üç ay sonra yapılan izleme ölçümünde de devam etmektedir.

Denence 2: 'Şiddetsiz Karşı Koyma' programının uygulandığı deney grubu ebeveynlerinin kontrol grubu ebeveynlerine göre 'Anne Baba Stres Düzeyi Ölçeği' son-test puanları ön-test puanlarından anlamlı düzeyde düşüktür ve bu fark üç ay sonra yapılan izleme ölçümünde de devam etmektedir.

Denence 3: 'Şiddetsiz Karşı Koyma' programının uygulandığı deney grubu ebeveynlerinin kontrol grubu ebeveynlerine göre çocuklarında algıladıkları şiddet düzeyi son-test puanları ön-test puanlarından anlamlı düzeyde düşüktür ve bu fark üç ay sonra yapılan izleme ölçümünde de devam etmektedir.

Denence 4: 'Şiddetsiz Karşı Koyma' programının uygulandığı deney grubu ebeveynlerinin kontrol grubu ebeveynlerine göre bir ebeveyn olarak kendilerinde algıladıkları yetersizlik düzeyi son-test puanları ön-test puanlarından anlamlı düzeyde düşüktür ve bu fark üç ay sonra yapılan izleme ölçümünde de devam etmektedir.

Denence 5: 'Şiddetsiz Karşı Koyma' programının uygulandığı deney grubu ebeveynlerinin kontrol grubu ebeveynlerine göre bir ebeveyn olarak algıladıkları destek düzeyi son-test puanları ön-test puanlarından anlamlı düzeyde yüksektir ve bu fark üç ay sonra yapılan izleme ölçümünde de devam etmektedir.

\section{Yöntem}

\section{Araştırmanın Modeli}

Bu araştırma katılımcıların gönüllüğü çerçevesinde yarı deneysel bir model olarak kurgulanmıştır. Araştırmaya katılmaya gönüllü ebeveynlerin deney ve kontrol gruplarına atanması işlemi denek çiftlerinin oluşturulması, yani eşleştirme yöntemine göre yapılmıştır. Yarı deneysel çalışmalarda katılımcıların çalışma gruplarına tesadüfi olarak atanması oldukça güçtür. Bağımlı değişken dışında bazı değişkenleri manipule etmek gerekebilir (Heppner, Wampold ve Kivlighan, 2013). Bu araştırmada, ekonomik gelir düzeyi ve ebeveynlerin herhangi bir psikolojik yardım almıyor olması gibi bazı değişkenler kontrol altına alınırken; babaların grup eğitimlerine süreklilik içeren bir şekilde katılamayacaklarını belirtmesi sebebiyle cinsiyete göre yansız atama yapılamamıştır. Bu sebeple deney ve kontrol grupları annelerden oluşturulmuştur.

\section{Çalışma Grubu}

Araştırmanın çalışma grubu, Niğde ilinde bir ilkokul kurumunda 2016-2017 eğitim-öğretim yılında öğrenimlerine devam eden ve okul içinde arkadaşlarını itme, vurma, eşyalara zarar verme, küfür ve hakaret etme gibi kaba ve disiplinsiz davranışlarıyla ilgili problemler yaşayan öğrencilerin ebeveynlerinden oluşmuştur. Okul içerisinde şiddet içeren ve istenmeyen bu tür davranışları sebebiyle sınıf öğretmeni ve okul idarecileri tarafindan okul psikolojik danışma ve rehberlik servisine yönlendirilen öğrencilerin ebeveynleri arasından araştırmaya katılmaya gönüllü 16 ebeveyn (8 deney-8 kontrol) deney ve kontrol gruplarına atanmıştır. Deney ve kontrol grup puanlarının normal dağılım özelliği göstermemesinden dolayı grupların ön-test puan ortalamaları arasındaki farka non-parametrik testlerden biri olan Mann Withney U testi ile bakılmış ve sonuçlar Tablo 1'te sunulmuştur. 
Tablo 1. Deney ve Kontrol Gruplarının Aile Değerlendirme Ölçeği Toplam Puanı, Alt Ölçekleri (Problem Çözme, iletişim, Roller, Duygusal Tepki Verebilme, Gereken ilgiyi Gösterme, Davranış Kontrolü ve Genel İ̧̧levler), Anne Baba Stres Ölçeği ve Ebeveynlerin Algıladıkları Şiddet, Yetersizlik ve Destek Düzeyi Ön-test Puanlarına İlişkin Mann Whitney U Testi Sonuçları

\begin{tabular}{|c|c|c|c|c|c|c|}
\hline Ölçüm & Gruplar & $\mathrm{n}$ & Sıra Ortalaması & Sıra Toplamı & $U$ & $\mathrm{p}$ \\
\hline \multirow{2}{*}{ ADÖ } & Deney & 8 & 9.25 & 74.00 & \multirow{2}{*}{26.00} & \multirow{2}{*}{.52} \\
\hline & Kontrol & 8 & 7.75 & 62.00 & & \\
\hline \multirow[t]{2}{*}{ Problem çözme } & Deney & 8 & 10.25 & 82.00 & \multirow{2}{*}{18.00} & \multirow{2}{*}{.13} \\
\hline & Kontrol & 8 & 6.75 & 54.00 & & \\
\hline \multirow[t]{2}{*}{ İletişim } & Deney & 8 & 9.69 & 77.50 & \multirow{2}{*}{22.50} & \multirow{2}{*}{.31} \\
\hline & Kontrol & 8 & 7.31 & 58.50 & & \\
\hline \multirow{2}{*}{ Roller } & Deney & 8 & 9.44 & 75.50 & \multirow{2}{*}{24.50} & \multirow{2}{*}{.42} \\
\hline & Kontrol & 8 & 7.56 & 60.50 & & \\
\hline \multirow{2}{*}{ Duygusal tepki verebilme } & Deney & 8 & 10.56 & 84.50 & \multirow{2}{*}{15.50} & \multirow{2}{*}{.07} \\
\hline & Kontrol & 8 & 6.44 & 51.50 & & \\
\hline \multirow{2}{*}{ Gereken ilgiyi gösterme } & Deney & 8 & 8.50 & 68.00 & \multirow{2}{*}{32.00} & \multirow{2}{*}{1.00} \\
\hline & Kontrol & 8 & 8.50 & 68.00 & & \\
\hline \multirow{2}{*}{ Davranış kontrolü } & Deney & 8 & 8.25 & 66.00 & \multirow{2}{*}{30.00} & \multirow{2}{*}{.83} \\
\hline & Kontrol & 8 & 8.75 & 70.00 & & \\
\hline \multirow{2}{*}{ Genel işlevler } & Deney & 8 & 10.19 & 81.50 & \multirow{2}{*}{18.50} & \multirow{2}{*}{.15} \\
\hline & Kontrol & 8 & 6.81 & 54.50 & & \\
\hline \multirow{2}{*}{ Stres düzeyi } & Deney & 8 & 10.13 & 81.00 & \multirow{2}{*}{19.00} & \multirow{2}{*}{.17} \\
\hline & Kontrol & 8 & 6.88 & 55.00 & & \\
\hline \multirow{2}{*}{ Şiddet } & Deney & 8 & 10.06 & 80.50 & \multirow{2}{*}{19.50} & \multirow{2}{*}{.18} \\
\hline & Kontrol & 8 & 6.94 & 55.50 & & \\
\hline \multirow{2}{*}{ Yetersizlik } & Deney & 8 & 8.50 & 68.00 & \multirow{2}{*}{32.00} & \multirow{2}{*}{1.00} \\
\hline & Kontrol & 8 & 8.50 & 68.00 & & \\
\hline Destek & Deney & 8 & 7.31 & 58.50 & & \\
\hline Destek & Kontrol & 8 & 9.69 & 77.50 & 22.50 & .31 \\
\hline
\end{tabular}

Tablo 1'de görüldüğü gibi deney ve kontrol gruplarına atanan ebeveynlere uygulanan 'ADÖ' toplam puanı, alt ölçekleri ve ebeveynlerin algıladıkları stres, şiddet, yetersizlik ve destek düzeyi öntest puanları arasında anlamlı bir farklıık olmadığı ortaya çıkmıştır. Bu sonuçlardan hareketle deney ve kontrol gruplarının öntest puanları açısından denk olduğu söylenebilir.

\section{Veri Toplama Araçları}

Araştırmada ebeveynlerin etkileşim ağı ve aile içi ilişkilerini değerlendirmek için Aile Değerlendirme Ölçeği, bununla birlikte Anne Baba Stres Ölçeği ve ebeveynleri çocuklarında algıladıkları şiddet düzeyi, yetersizlik ve destek algılarını ortaya çıkarabilmek için de Öznel Rahatsızlık Birimleri Ölçeği (SUDS) uygulanmıştır.

\section{Aile Değerlendirme ölçeği (ADö)}

Aile Değerlendirme Ölçeği (McMaster Family Assesment Device) ABD'de Brown Üniversitesi ve Butler Hastanesi tarafindan Aile Araştırma Programı çerçevesinde Epstein, Baldwin ve Bishop (1983) tarafindan aile işlevlerini çeşitli boyutlarda ölçmek üzere geliştirilmiştir. On iki yaş üzerindeki tüm aile üyelerine ve deneğin kendisine aile işlevlerini değerlendirmek amacıyla uygulanabilmektedir. Problem Çözme (PRÇ), iletişim (iLT), Roller (ROL), Duygusal Tepki Verebilme (DTV), Gereken ilgiyi Gösterme (GIG), Davranış Kontrolü (DVK) ve Genel Fonksiyonlar (GNF) adı altında 7 alt ölçekten oluşan Aile Değerlendirme Ölçeği 60 maddedir. Ölçek "Aynen kathlıyorum" (1 puan) ile "Hiç katılmıyorum" (4 puan) arasında değişen dört seçenek üzerinden puanlanmaktadır. Ölçekte " 1 " puan sağlıklı, "4" puan sağlıksız cevabının göstergesidir, 35 madde tersine çevrilmiş maddedir. Yüksek puan o işlev açısından sağlıksızlığın arttğ̆ını gösterir. Orjinal ölçeğin iç tutarlıık (alfa katsayısı) alt boyutta 0.72 ile 0.92 arasında değişmektedir. Bu da ölçeğin iç tutarlıı̆ğının yüksek olduğunu göstermektedir. Ölçeğin geçerlik çalışması Epstein ve arkadaşları tarafindan yapılmıştı (1983). Ölçek, 218 normal 98 psikiyatrik hasta ailesinden yalnız birer kişiye uygulanmış, her ölçekte normal ailelerin aldıkları puan ortalamaları hasta ailelerin aldıkları puan ortalamalarından daha düşük (sağlıkı) çıkmıştr. Ölçeğin Türkçe uyarlama çalışması Bulut (1990) tarafindan yapılmıştır. Alt ölçeklerin Cronbach-alfa ile değerlendirilen iç tutarlık katsayıları .38 ile .86 arasında değişmektedir. Ölçeğin yapı geçerliği boşanma sürecinde olan ve olmayan grupların aldıkları puanlar karşılaştırılarak değerlendirilmiştir. Ölçeğin bu iki grubu anlamlı düzeyde ayırt ettiği bulunmuştur. 


\section{Anne-Baba Stres Ölçeği (ABSÖ)}

Anne-Baba Stres Düzeyi Ölçeği (ABSÖ) anne babaların günlük yaşamda çocukları ile ilişkilerinde yaşadıkları stresi ölçmeye yönelik bir araç olarak Özmen ve Özmen (2012) tarafindan geliştirilmiştir. ABSÖ’nün geçerlik çalışmaları kapsamında yapı geçerliği incelenmiştir. Açımlayıı faktör analizi sonucunda varyansın \%32.20'sini açıklayan, 16 maddeden oluşan tek boyutlu bir ölçek elde edilmiştir. ABSÖ’nün içtutarlıık güvenirliği için hesaplanan Cronbach Alfa değeri .85 ve Spearman Brown İkiyarı test güvenirliği .82 olarak hesaplanmıştr. Ölçekte yer alan tüm maddeler için madde toplam korelasyonları ise .34 ile .58 arasında değişmektedir. Madde analizi kapsamında elde edilen t değerlerinin anlamlı olduğu ( $p<$.001) görülmüştür. Sonuç olarak, Anne Baba Stres Ölçeği (ABSÖ), 16 maddeden oluşan tek boyutlu bir ölçektir. Ölçekte dörtlü Likert tipi bir derecelendirme (Her zaman=4, Sık sık=3, Bazen=2, Hiçbir zaman=1) kullanılmıştır. Ölçekten alınabilecek en düşük puan 16 , en yüksek puan $64^{\prime}$ tür. Ölçekten alınan yüksek puan, anne baba stresinin yüksek olduğunu göstermektedir.

\section{Öznel Rahatsızlık Birimleri (SUDS) Anketi}

Öznel Rahatsızlık Birimleri Anketi (SUDS) Güney Afrikalı psikiyatrist Joseph Wolpe tarafindan 1969 yılında geliştirilmiştir. Wolpe, "SUDS" anketini insanlara kendi rahatsızlık seviyelerini endişeli ve korkulu hissettikleri belirli durumlarda 0 ile 10 arasında bir derecelendirme ölçeği üzerinde belirlemeye yardım etmek için kullanmıştır. Araştırmada kullanılan anket formu çerçevesinde ebeveynlere onları ilgilendiren üç temel alan hakkında sorular sorulmuştur: a. çocuklarında algıladıkları şiddet düzeyi, b. kendi ebeveynlik becerilerine yönelik yetersizlik ve c. çocuklarında görülen saldırganlık içeren tutum ve davranışlarla baş etmek konusunda algıladıkları destek düzeyi. SUDS anketi, bu araştrmada ebeveynlere süreç içerisinde bir şeylerin değiştiğini hissedip hissetmediğini değerlendirmede yardım etmek amacıyla kullanılmıştır.

\section{Deneysel İşlem}

Ebeveynlere yönelik 'Şiddetsiz Karşı Koyma' programı, deney grubuna katılan ebeveynlerle haftada bir kez, yaklaşık 90 dakikalık oturumlar halinde yürütülmüştür. Uygulamalar araştırmacı tarafindan ebeveynlere hafta içi öğlen saatlerinde uygulanmıştır. Ebeveyn gruplarının uygulamaları çocuklarının devam ettiği okulda, grup toplant salonunda, üyelerin çember biçiminde rahatça oturabilecekleri ve etkinliklerin yapılmasına olanak verecek bir ortamda yapılmıştır. Katılımcılara program öncesi detaylı bilgi verilerek bilgilendirilmiş onam formu alınmıştır. Ebeveyn oturumlarına etkinlikler hakkında bilgilendirmeler ve ısınma aktiviteleri ile başlanmış, grup aktiviteleri, yaşanılanlara dair bireysel ve grup paylaşımları ve tartışmalar ile sürdürülmüştür. Araştırmacı Ocak ve Şubat 2016 tarihlerinde Avusturya'nın Graz şehrinde akredite olmuş bir kurumdan (Institut für Kind, Jugend und Familie) Şiddetsiz Karşı Koyma temel eğitim (alt gün) ve ileri düzey eğitimlerini (alt gün) tamamlamıştır. Bu eğitim çerçevesinde program içindeki etkinliklerin Türk kültür ve aile yapısına uyarlama çalışmalarını yapmak için alan uzmanlarından destek alınmıştır. Deney grubu ile yürütülen çalışmalar sırasında, kontrol grubu ebeveynlerine yönelik olarak da katılımcıların çocuklarının eğitsel gelişimi ve mesleki ilgilerine yönelik iki haftalık kısa süreli eğitsel ve mesleki rehberlik etkinlikleri yürütülmüştür.

\section{Şiddetsiz Karşı Koyma Programı (Non-Violent Resistance Program-NVR)}

Araştırma kapsamında şiddet ve saldırganlık davranışları olan öğrencilerin ebeveynlerinden oluşan deney grubuna, 14 oturumluk Şiddetsiz Karşı Koyma (NVR) ebeveyn programı (Day ve Heismann, 2010) uygulanmıştr. Programın ana hatları incelendiğinde birinci oturumda ebeveynlerle ailede ortak gerginlik artışını farketme, gerginliği kabullenme, gerginlik artışına karşı direnmek ve ebeveynlerin kendi gerginliklerini kontrol edebilmeleri üzerinde çalışılmıştır. ikinci oturumda, anne-babaların ev içinde ebeveynsel varlığını hissettirme ve olası destek kaynakları üzerinde düşünmeleri üzerinde durulmuştur. Üçüncü oturumda, ebeveynlerin problemlerini öncelik sırasına göre düzenleyebilme ve tüm problemlere reaksiyon gösterek kaynaklarını tüketmektense, aile için en kritik olanlara odaklanabilmeleri üzerinde durulmuştur. Dördüncü oturumda, evebeveynlerin destekleyiciler ve destek sistemleri oluşturması, belirlemiş oldukları destekleyicilerin hangi problem davranışlarla nasıl yardım edebilecekleri üzerinde tartışılmıştr. Beşinci oturumda, ebeveynlerin kendi seslerini şiddet kullanmadan etkin bir biçimde duyurabilmelerine yardım eden 'duyuru' tekniği üzerinde çalışıımıştr. Altıncı oturumda, anne-babaların ebeveynsel değerlerinin nasıl oluştuğu ve çocukları ile olan ilişkilerini bu değerlerin nasıl etkilediği üzerinde durulmuştur. Yedinci oturumda, ebeveynlerin çocuklarının gösterdiği şiddete karşı saldırmadan ve aktif bir biçimde nasıl direnç gösterebilecekleri ve çocukları ile uzlaşma eylemlerini artırabilmeleri üzerinde durulmuştur. Sekizinci oturumda, rol oynama teknikleri kullanılarak ebeveynlerin şiddete karşı direncini artrabilecek 'oturma eylemi' etkinliği üzerinde durulmuştur. Dokuzuncu oturumda, anne-babaların ev dışında ebeveynsel varlığını artırabilmelerine ilişkin farkındalıklarının ve girişimlerinin artırılması hedeflenmiştir. Onuncu oturumda, erkek ve kız kardeşlerin şiddetten korunmalarına yardımcı olmaları konusunda ebeveynlerin yapabilecekleri üzerinde durulmuş ve tüm sürecin ebeveynlerle birlikte özetlenmesi yapılmıştr. 
Sonraki dört oturumda, evebevnlerin tüm programa ilişkin kazanımlarının güçlendirilmesi amacıyla programın kritik etkinliklerinden olan 'duyuru yapma', 'oturma eylemi', 'uzlaşma eylemleri ve ebeveynlerin kendilerini daha iyi hissedecekleri etkinlikler oluşturmayı içeren kendine iyi bakma çalışmaları yapılmıştı. Buna ek olarak, NVR programı sonunda ebeveynlerin aile etkileşim ağının çocuklarının tutum ve davranışlarına etkisi ve çocukların bireysel tutum ve davranışlarının aile yapısı ve etkileşimleri üzerindeki etkilerini fark etmek amacıyla 'aile soy ağacı (genogram)' ve 'aile dizimi' etkinlikleri yapılarak, ebeveynlerin kendi duygu ve düşüncelerini paylaşmaları teşvik edilmiştir. Ebeveynlerle yürütülen grup çalışmaları sürecinde küçük grup aktiviteleri, rol oynama ve video izleme gibi tekniklerinden faydalanılmıştır.

\section{Verilerin Analizi}

Bu araştırma kapsamında şiddet ve saldırganlık davranışları olan öğrencilerin ebeveynlerinden oluşan deney grubuna, Şiddetsiz Karşı Koyma (NVR) ebeveyn programı (Day ve Heismann, 2010) uygulanmıştı. Araştırmanın verileri deney ve kontrol grubunda bulunan ebeveynlere uygulanan Aile Değerlendirme Ölçeği, Anne Baba Stres Ölçeği ve bununla birlikte yaşanan ebeveynlerin çocuklarında gördükleri şiddet düzeyi, ebeveyn yeterlilik ve destek algılarına dair Öznel Rahatsızlık Birimleri Anketi aracılığıyla elde edilmiştir. Söz konusu ölçekler deney ve kontrol grubu ebeveynlerine ön-test, son-test ve izleme ölçümleri olarak uygulanmıştr. Araştırma verilerinin analizinde SPSS 22 paket programı kullanılmıştır. Verilerin analizi sürecinde grupların söz konusu ölçme araçlarından aldıkları puanların normal dağılım özelliği göstermemesi sebebiyle, parametrik olmayan testlerden Mann Whitney U testi ve Wilcoxon İşaretli Sıralar Testi kullanılmıştır. İzleme ölçümü için, son-test ölçümlerinin bitiminden üç ay sonra deney ve kontrol grubunda bulunan ebeveynlere telefon aracılığıyla ulaşılarak randevu alınmış ve programın yürütüldüğü okulda tüm grup buluşularak izleme veriler toplanmıştir.

\section{Bulgular}

Analiz sonuçları incelendiğinde, uygulanan programların ebeveynlerin Aile Değerlendirme Ölçeği toplam puanı ve bazı alt ölçekleri (Roller, Duygusal Tepki Verebilme, Gereken illgiyi Gösterme ve Genel Işlevler) açısından anlamlı düzeyde etkili olduğunu göstermektedir. Uygulanan program ile deney grubuna katılan ebeveynlerin çocuklarının göstermiş oldukları saldırganlık içeren tutum ve davranışlara yönelik algılarını, hissetmiş oldukları yetersizlik duygularını ve stres düzeylerini anlamlı derecede düşürdüğü görülmüştür. Bununla birlikte, deney grubuna katilan ebeveynlerin algılamış oldukları destek miktarının program sonunda anlamlı düzeyde arttğı görülmüştür. Araştırmadan elde edilen bulgular denence sırasına uygun olarak aşağıda sunulmuştur.

Denence 1: 'Şiddetsiz Karşı Koyma' programının uygulandığı deney grubu ebeveynlerinin kontrol grubu ebeveynlerine göre 'Aile Değerlendirme Ölçeği' toplam puanı ve alt ölçeklerinden (Problem Çözme, iletişim, Roller, Duygusal Tepki Verebilme, Gereken Ilgiyi Gösterme, Davranış Kontrolü ve Genel Işslevler) aldıkları sontest puanları öntest puanlarından anlamlı düzeyde düşüktür ve bu fark üç ay sonra yapılan izleme ölçümünde de devam etmektedir.

Deney ve kontrol grubunda bulunan öğrencilerin Aile Değerlendirme Ölçeği ve Problem Çözme, iletişim, Roller, Duygusal Tepki Verebilme, Gereken Illgiyi Gösterme, Davranış Kontrolü ve Genel İşlevler Alt Ölçeklerinden aldıkları ön-test ve son-test puan ortalamaları arasında farklıııklar olduğu görülmüştür. Araştırmanın birinci denencesini sınamaya yönelik verilerin analizi aşamasında, grupların söz konusu ölçme aracından aldıkları puanların normal dağıım özelliği göstermemesi sebebiyle, parametrik olmayan testlerden biri olan Wilcoxon İşaretli Sıralar Testi uygulanarak deney ve kontrol grubundaki anne-babaların ön-test ve son-test puanları arasında anlamlı bir farklııı olup olmadığına bakılmıştır. Analiz sürecinde deney ve kontrol grubuna ait veriler ayrı ayrı analiz edilmiş, elde edilen bulgular Tablo 2'de verilmiştir.

Tablo 2. Deney ve Kontrol Grubundaki Ebeveynlerin Aile Değerlendirme Ölçeği Toplam Puanı ve Problem Çözme, illetişim, Roller, Duygusal Tepki Verebilme, Gereken illgiyi Gösterme, Davranış Kontrolü ve Genel İşlevler Alt Ölçekleri Ön-test ve Son-test Puanlarına ilişkin Wilcoxon İşaretli Sıralar Testi Analiz Sonuçları

\begin{tabular}{|c|c|c|c|c|c|c|}
\hline Gruplar & Sontest-Öntest & $\mathrm{n}$ & Sıra Ortalamaları & Sıra Toplamı & Z & $\mathrm{p}$ \\
\hline \multirow{3}{*}{$\begin{array}{l}\text { ADÖ Toplam } \\
\text { Puan } \\
\text { Deney Grubu }\end{array}$} & Negatif Sıra & 7 & 4.86 & 34.00 & & \\
\hline & Pozitif Sıra & 1 & 2.00 & 2.00 & -2.240 & $.02 *$ \\
\hline & Eşit & 0 & & & & \\
\hline \multirow{3}{*}{$\begin{array}{l}\text { ADÖ Toplam } \\
\text { Puan } \\
\text { Kontrol Grubu }\end{array}$} & Negatif Sıra & 5 & 5.00 & 25.00 & & \\
\hline & Pozitif Sıra & 2 & 1.50 & 3.00 & -1.859 & .06 \\
\hline & Eşit & 1 & & & & \\
\hline
\end{tabular}




\begin{tabular}{|c|c|c|c|c|c|c|}
\hline Gruplar & Sontest-Öntest & $\mathrm{n}$ & Sıra Ortalamaları & Sıra Toplamı & Z & $p$ \\
\hline \multirow{3}{*}{$\begin{array}{l}\text { Problem çözme } \\
\text { Deney Grubu }\end{array}$} & Negatif Sıra & 3 & 5.00 & 15.00 & & \\
\hline & Pozitif Sıra & 3 & 2.00 & 6.00 & -954 & .34 \\
\hline & Eşit & 2 & & & & \\
\hline \multirow{3}{*}{$\begin{array}{l}\text { Problem çözme } \\
\text { Kontrol Grubu }\end{array}$} & Negatif Sıra & 2 & 3.50 & 7.00 & & \\
\hline & Pozitif Sıra & 3 & 2.67 & 8.00 & -.135 & .89 \\
\hline & Eşit & 3 & & & & \\
\hline \multirow{3}{*}{$\begin{array}{l}\text { İletişim } \\
\text { Deney Grubu }\end{array}$} & Negatif Sıra & 5 & 5.40 & 27.00 & & \\
\hline & Pozitif Sıra & 3 & 3.00 & 9.00 & -1.263 & .20 \\
\hline & Eşit & 0 & & & & \\
\hline İletişim & Negatif Sıra & 5 & 4.10 & 20.50 & & \\
\hline \multirow[t]{2}{*}{ Kontrol Grubu } & Pozitif Sıra & 2 & 3.75 & 7.50 & -1.119 & .26 \\
\hline & Eşit & 1 & & & & \\
\hline \multirow{3}{*}{$\begin{array}{l}\text { Roller } \\
\text { Deney Grubu }\end{array}$} & Negatif Sıra & 7 & 4.86 & 34.00 & & \\
\hline & Pozitif Sıra & 1 & 2.00 & 2.00 & -2.252 & $.02 *$ \\
\hline & Eşit & 0 & & & & \\
\hline \multirow{3}{*}{$\begin{array}{l}\text { Roller } \\
\text { Kontrol Grubu }\end{array}$} & Negatif Sıra & 6 & 4.08 & 24.50 & & \\
\hline & Pozitif Sıra & 1 & 3.50 & 3.50 & -1.781 & .07 \\
\hline & Eşit & 1 & & & & \\
\hline \multirow{3}{*}{$\begin{array}{l}\text { Duygusal tepki } \\
\text { verebilme } \\
\text { Deney Grubu }\end{array}$} & Negatif Sıra & 8 & 4.50 & 36.00 & & \\
\hline & Pozitif Sıra & 0 & .00 & .00 & -2.555 & $.01 *$ \\
\hline & Eşit & 0 & & & & \\
\hline \multirow{3}{*}{$\begin{array}{l}\text { Duygusal tepki } \\
\text { verebilme } \\
\text { Kontrol Grubu }\end{array}$} & Negatif Sıra & 2 & 3.00 & 6.00 & & \\
\hline & Pozitif Sıra & 2 & 2.00 & 4.00 & -.365 & .71 \\
\hline & Eşit & 4 & & & & \\
\hline \multirow{3}{*}{$\begin{array}{l}\text { Gereken ilgiyi } \\
\text { gösterme } \\
\text { Deney Grubu }\end{array}$} & Negatif Sıra & 6 & 5.50 & 33.00 & & \\
\hline & Pozitif Sıra & 2 & 1.50 & 3.00 & -2.108 & $.03 *$ \\
\hline & Eşit & 0 & & & & \\
\hline \multirow{3}{*}{$\begin{array}{l}\text { Gereken ilgiyi } \\
\text { gösterme } \\
\text { Kontrol Grubu }\end{array}$} & Negatif Sıra & 4 & 3.13 & 12.50 & & \\
\hline & Pozitif Sıra & 3 & 5.17 & 15.50 & -.256 & .79 \\
\hline & Eşit & 1 & & & & \\
\hline \multirow{3}{*}{$\begin{array}{l}\text { Davranış kontrolü } \\
\text { Deney Grubu }\end{array}$} & Negatif Sıra & 5 & 4.70 & 23.50 & & \\
\hline & Pozitif Sıra & 3 & 4.17 & 12.50 & -.775 & .43 \\
\hline & Eşit & 0 & & & & \\
\hline \multirow{3}{*}{$\begin{array}{l}\text { Davranış kontrolü } \\
\text { Kontrol Grubu }\end{array}$} & Negatif Sıra & 5 & 3.40 & 17.00 & & \\
\hline & Pozitif Sıra & 2 & 5.50 & 11.00 & -.509 & .61 \\
\hline & Eşit & 1 & & & & \\
\hline \multirow{3}{*}{$\begin{array}{l}\text { Genel işlevler } \\
\text { Deney Grubu }\end{array}$} & Negatif Sıra & 6 & 4.33 & 26.00 & & \\
\hline & Pozitif Sıra & 1 & 2.00 & 2.00 & -2.032 & $.04 *$ \\
\hline & Eşit & 1 & & & & \\
\hline \multirow{3}{*}{$\begin{array}{l}\text { Genel işlevler } \\
\text { Kontrol Grubu }\end{array}$} & Negatif Sıra & 5 & 4.60 & 23.00 & & \\
\hline & Pozitif Sıra & 2 & 2.50 & 5.00 & -1.549 & .12 \\
\hline & Eşit & 1 & & & & \\
\hline
\end{tabular}

Tablo 2 incelendiğinde deney grubundaki anne-babaların "Aile Değerlendirme Ölçeği" toplam puan ortalamaları $(Z=-2.240 ; p<.05)$; Roller ( $Z=-2.252 ; p<.05)$; Duygusal Tepki Verebilme $(Z=-2.555 ; p<.05)$; Gereken Ilgiyi Gösterme $(Z=$ -2.108; $p<.05)$ ve Genel İşlevler $(Z=-2.032 ; p<.05)$ alt ölçekleri ön-test ve son-test puanları arasında anlamlı bir farklılığın olduğu görülürken; Problem Çözme ( $Z=-954 ; p>.05)$; Iletişim ( $Z=-1.263 ; p>.05)$ ve Davranış Kontrolü alt ölçekleri ( $Z=-.775 ; p>~ .05)$ ön-test ve son-test puanları arasında anlamlı bir farklılığın olmadığı görülmüştür.

Kontrol grubundaki ebeveynlerin puanları incelendiğinde ise ön-test ve son-test puan ortalamaları arasında anlamlı bir farklılığın olmadığı (ADÖ Toplam; $Z=-1.859 ; p>.05$; Problem Çözme: $Z=-135 ; p>.05$; Illetişim: $Z=-1.119 ; p>.05$ ), Roller: $Z=-1.781 ; p>.05$; Duygusal Tepki Verebilme: $Z=-.365 ; p>.05$; Gereken Ilgiyi Gösterme: $Z=-.256 ; p>.05$; Davranış Kontrolü: $Z=-.509 ; p>~ .05$; Genel İşlevler: $Z=-1.549 ; p>.05$ ) görülmüştür. 
Bu sonuç ile deney grubundaki ebeveynlerin aile değerlendirme ölçeği öntest puanlarının sontest puanlarında düşüş göstermesi dikkate alındığında, uygulanan programın "ADÖ" toplam puanları, Roller, Duygusal Tepki Verebilme, Gereken İlgiyi Gösterme ve Genel İşlevler alt ölçekleri bakımından ebeveynlerin sağlıklı aile işlevselliği algıları üzerinde önemli bir etkisinin olduğu söylenebilir.

Deney grubundaki ebeveynlerin 'Aile Değerlendirme Ölçeği' toplam puanı ve alt ölçeklerinin son-test ve izleme testi ölçümlerinden aldıkları puanlar arasındaki farklılığı sınamak amacıyla yapılan Wilcoxon İşaretli Sıralar Testi analizinden elde edilen sonuçlar Tablo 3' te yer almaktadır.

Tablo 3. Deney Grubundaki Ebeveynlerin Aile Değerlendirme Ölçeği Toplam Puanı, Problem Çözme, İletişim, Roller, Duygusal Tepki Verebilme, Gereken ilgiyi Gösterme, Davranış Kontrolü ve Genel İ̧̧levler Alt Ölçekleri Sontest ve İzleme Testi Puanlarına İlişkin Wilcoxon İşaretli Sıralar Testi Analiz Sonuçları

\begin{tabular}{|c|c|c|c|c|c|c|}
\hline Gruplar & İzleme-Sontest & $\mathrm{n}$ & Sıra Ortalamaları & Sıra Toplamı & Z & $\mathrm{p}$ \\
\hline \multirow{3}{*}{$\begin{array}{l}\text { ADÖ } \\
\text { Toplam Puan }\end{array}$} & Negatif Sıra & 4 & 3.50 & 14.00 & \multirow{3}{*}{-.000} & \multirow{3}{*}{1.00} \\
\hline & Pozitif Sıra & 3 & 4.67 & 14.00 & & \\
\hline & Eşit & 1 & & & & \\
\hline \multirow{3}{*}{ Problem çözme } & Negatif Sıra & 5 & 3.20 & 16.00 & \multirow{3}{*}{-.283} & \multirow{3}{*}{.77} \\
\hline & Pozitif Sıra & 3 & 6.67 & 20.00 & & \\
\hline & Eşit & 0 & & & & \\
\hline \multirow{3}{*}{ İletişim } & Negatif Sıra & 5 & 4.20 & 21.00 & \multirow{3}{*}{-.424} & \multirow{3}{*}{.67} \\
\hline & Pozitif Sıra & 3 & 5.00 & 15.00 & & \\
\hline & Eşit & 0 & & & & \\
\hline \multirow{3}{*}{ Roller } & Negatif Sıra & 2 & 3.00 & 6.00 & \multirow{3}{*}{-1.703} & \multirow{3}{*}{.08} \\
\hline & Pozitif Sıra & 6 & 5.00 & 30.00 & & \\
\hline & Eşit & 0 & & & & \\
\hline \multirow{3}{*}{$\begin{array}{l}\text { Duygusal Tepki Vere- } \\
\text { bilme }\end{array}$} & Negatif Sıra & 2 & 4.00 & 8.00 & \multirow{3}{*}{$-.1 .023$} & \multirow{3}{*}{.30} \\
\hline & Pozitif Sıra & 5 & 4.00 & 20.00 & & \\
\hline & Eşit & 1 & & & & \\
\hline \multirow{3}{*}{$\begin{array}{l}\text { Gereken ilgiyi Gös- } \\
\text { terme }\end{array}$} & Negatif Sıra & 1 & 1.00 & 1.00 & \multirow{3}{*}{-1.473} & \multirow{3}{*}{.14} \\
\hline & Pozitif Sıra & 3 & 3.00 & 9.00 & & \\
\hline & Eşit & 4 & & & & \\
\hline \multirow{3}{*}{ Davranış Kontrolü } & Negatif Sıra & 4 & 5.00 & 20.00 & \multirow{3}{*}{-.288} & \multirow{3}{*}{.77} \\
\hline & Pozitif Sıra & 4 & 4.00 & 16.00 & & \\
\hline & Eşit & 0 & & & & \\
\hline \multirow{3}{*}{ Genel İşlevler } & Negatif Sıra & 2 & 3.75 & 7.50 & \multirow{3}{*}{-1.121} & \multirow{3}{*}{.26} \\
\hline & Pozitif Sıra & 5 & 4.10 & 20.50 & & \\
\hline & Eşit & 1 & & & & \\
\hline
\end{tabular}

Tablo 3 incelendiğinde deney grubuna katlan ebeveynlerin Aile Değerlendirme Ölçeği ve Alt Ölçekleri son-test ve izleme testi puanları arasında anlamlı bir farklıık olup olmadığını belirlemek için yapılan Wilcoxon İşaretli Sıralar Testi sonuçlarına göre, son-test ve izleme testi puanları arasında anlamlı bir farklılığın olmadığı görülmektedir (ADÖ toplam puan: $Z=-.000$; Problem Çözme: $Z=-283 ; p>.05$; Iletişim: $Z=-424 ; p>$.05; Roller: $Z=-.1 .703 ; p>.05$; Duygusal Tepki Verebilme: $Z=-1.023 ; p>.05$; Gereken İlgiyi Gösterme: $Z=-1.473 ; p>.05$; Davranış Kontrolü: $Z=-.288 ; p>.05$ ve Genel Isşlevler: $Z=-1.121 ; p>.05)$.

Denence 2: 'Şiddetsiz Karşı Koyma' programının uygulandığı deney grubu ebeveynlerinin kontrol grubu ebeveynlerine göre 'Anne Baba Stres Düzeyi Ölçeği' son-test puanları ön-test puanlarından anlamlı düzeyde düşüktür ve bu fark üç ay sonra yapılan izleme ölçümünde devam etmektedir.

Araştırmanın ikinci denencesini sınamaya yönelik verilerin analizi aşamasında, grupların söz konusu ölçme aracından aldıkları puanların normal dağılım özelliği göstermemesi sebebiyle, parametrik olmayan testlerden biri olan Wilcoxon İşaretli Sıralar Testi uygulanarak deney ve kontrol grubundaki ebeveynlerin ön-test ve son-test puanları arasında anlamlı bir farklılık olup olmadığına bakılmıştır. Analiz sürecinde deney ve kontrol grubuna ait veriler ayrı ayrı analiz 
edilmiş, elde edilen bulgular Tablo 4'te verilmiştir.

Tablo 4. Deney ve Kontrol Grubundaki Ebeveynlerin Anne Baba Stres Düzeyi Ölçeği Ön-test ve Son-test Puanlarına îlişkin Wilcoxon İşaretli Sıralar Testi Analiz Sonuçları

\begin{tabular}{|c|c|c|c|c|c|c|}
\hline Gruplar & Sontest-Öntest & $\mathrm{n}$ & Sıra Ortalamaları & Sıra Toplamı & Z & $\mathrm{p}$ \\
\hline & Negatif Sıra & 8 & 4.50 & 36.00 & & \\
\hline \multirow[t]{3}{*}{ Deney Grubu } & Pozitif Sıra & 0 & .00 & .00 & -2.527 & $.01^{*}$ \\
\hline & Eşit & 0 & & & & \\
\hline & Negatif Sıra & 5 & 3.20 & 16.00 & & \\
\hline \multirow[t]{2}{*}{ Kontrol Grubu } & Pozitif Sıra & 1 & 5,00 & 5.00 & -1.156 & .24 \\
\hline & Eşit & 2 & & & & \\
\hline
\end{tabular}

Tablo 4 incelendiğinde deney grubundaki ebeveynlerin ön-test ve son-test puanları arasında anlamlı bir farklılığın olduğu $(Z=-2.527 ; p<.05)$, herhangi bir işlemin uygulanmadığı kontrol grubundaki ebeveynlerin ön-test ve son-test puanları arasında ise anlamlı bir farklııı̆ın olmadığı $(Z=-1.156 ; p>.05)$ görülmüştür. Bu sonuç ile deney grubundaki ebeveynlerin Anne Baba Stres Düzeyi Ölçeği ön-test puanlarının son-testte düşüş göstermesi dikkate alındığında, uygulanan programın ebeveynlerin stres düzeyleri üzerinde anlamlı bir etkisinin olduğu söylenebilir.

Deney grubundaki ebeveynlerin ABSÖ sontest ve izleme testi ölçümlerinden aldıkları puanlar arasındaki farklılı̆ı sınamak amacıyla yapılan Wilcoxon İşaretli Sıralar Testi analizinden elde edilen sonuçlar Tablo 5' te yer almaktadır.

Tablo 5. Deney Grubundaki Ebeveynlerin Anne Baba Stres Düzeyi Ölçeği Son-test ve İzleme Testi Puanlarına ilişskin Wilcoxon İşaretli Sıralar Testi Analiz Sonuçları

\begin{tabular}{llcccc}
\hline Sontest-izzleme & $\mathrm{n}$ & Sıra Ortalamaları & Sıra Toplamı & Z & $\mathrm{p}$ \\
\hline Negatif Sıra & 5 & 3.20 & 16.00 & & \\
Pozitif Sıra & 2 & 6.00 & 12.00 & -.339 & .73 \\
Eşit & 1 & & & & \\
\hline
\end{tabular}

Tablo 5 incelendiğinde deney grubuna kathlan ebeveynlerin 'Anne Baba Stres Düzeyi Ölçeği' son-test ve izleme testi puanları arasında anlamlı bir farklılı̆ın olmadığı $(Z=-.339 ; p>$.05) görülmektedir.

Denence 3: 'Şiddetsiz Karşı Koyma' programının uygulandığı deney grubu ebeveynlerinin kontrol grubu ebeveynlerine göre çocuklarında algıladıkları Şiddet Düzeyi son-test puanları ön-test puanlarından anlamlı düzeyde düşüktür ve bu fark üç ay sonra yapılan izleme ölçümünde devam etmektedir.

Araştırmanın üçüncü denencesini sınamak amacıyla parametrik olmayan testlerden biri olan Wilcoxon İşaretli Sıralar Testi uygulanmış deney ve kontrol grubundaki ebeveynlerin ön-test ve son-test puanları arasında anlamlı bir farklılık olup olmadığına bakılmıştı. Analiz sürecinde deney ve kontrol grubuna ait veriler ayrı ayrı analiz edilmiş, elde edilen bulgular Tablo 6'da verilmiştir.

Tablo 6. Deney ve Kontrol Grubundaki Ebeveynlerin Çocuklarında Algıladıkları Şiddet Düzeyi Ön-test ve Son-test Puanlarına ilişkin Wilcoxon İşaretli Sıralar Testi Analiz Sonuçları

\begin{tabular}{|c|c|c|c|c|c|c|}
\hline Gruplar & Sontest-Öntest & $\mathrm{n}$ & Sıra Ortalamaları & Sıra Toplamı & Z & $p$ \\
\hline \multirow{3}{*}{ Deney Grubu } & Negatif Sıra & 6 & 3.50 & 21.00 & & \\
\hline & Pozitif Sıra & 0 & .00 & .00 & -2.214 & $.02^{*}$ \\
\hline & Eşit & 2 & & & & \\
\hline \multirow{3}{*}{ Kontrol Grubu } & Negatif Sıra & 2 & 2.25 & 4.50 & & \\
\hline & Pozitif Sıra & 2 & 2.75 & 5.50 & -.184 & .85 \\
\hline & Eşit & 4 & & & & \\
\hline
\end{tabular}

Tablo 6 incelendiğinde deney grubundaki ebeveynlerin algıladıkları Şiddet Düzeyi'ne ilişkin ön-test ve son-test puanları arasında anlamlı bir farklıı̆ın olduğu $(Z=-2.214 ; p<.05)$, herhangi bir işlemin uygulanmadığı kontrol grubundaki ebeveynlerin ön-test ve son-test puanları arasında ise anlamlı bir farklılığın olmadığı $(Z=-184 ; p>.05)$ görülmüştür. Bu sonuç ile deney grubundaki ebeveynlerin çocuklarında algıladıkları şiddet düzeyi derecelendirme anketi ön-test puanlarının son-testte istenen yönde düşüş göstermesi dikkate alındı̆̆ında, uygulanan programın çocuklarda görülen şiddet davranışları üzerinde anlamlı bir etkisinin olduğu söylenebilir. 
Deney grubundaki ebeveynlerin çocuklarında algıladıkları şiddet düzeyi son-test ve izleme testi ölçümlerinden aldıkları puanlar arasındaki farklılı̆̆ sınamak amacıyla yapılan Wilcoxon İşaretli Sıralar Testi analizinden elde edilen sonuçlar Tablo 7' de yer almaktadır.

Tablo 7. Deney Grubundaki Ebeveynlerin Çocuklarında Algıladıkları Şiddet Düzeyi Son-test ve İzleme Testi Puanlarına İlişkin Wilcoxon İşaretli Sıralar Testi Analiz Sonuçları

\begin{tabular}{llcccc}
\hline Sontest-İzleme & $\mathrm{n}$ & Sıra Ortalamaları & Sıra Toplamı & $\mathrm{Z}$ & $\mathrm{p}$ \\
\hline Negatif Sıra & 1 & 4.00 & 4.00 & & \\
Pozitif Sıra & 3 & 2.00 & 6.00 & -.378 & .70 \\
Eşit & 4 & & & & \\
\hline
\end{tabular}

Tablo 7 incelendiğinde deney grubuna katılan ebeveynlerin 'Şiddet Düzeyi Derecelendirme Anketi' son-test ve izleme testi puanları arasında anlamlı bir farklılığın olmadığı $(Z=-.378 ; p>.05)$ görülmektedir.

Denence 4: 'Şiddetsiz Karşı Koyma' programının uygulandığı deney grubu ebeveynlerinin kontrol grubu ebeveynlerine göre bir ebeveyn olarak kendilerinde algıladıkları yetersizlik düzeyi son-test puanları ön-test puanlarından anlamlı düzeyde düşüktür ve bu fark üç ay sonra yapılan izleme ölçümünde devam etmektedir.

Araştırmanın dördüncü denencesini sınamaya yönelik verilerin analizi için parametrik olmayan testlerden biri olan Wilcoxon İşaretli Sıralar Testi uygulanmış, deney ve kontrol grubundaki ebeveynlerin ön-test ve son-test puanları arasında anlamlı bir farklılık olup olmadığına bakılmıştır. Analiz sürecinde deney ve kontrol grubuna ait veriler ayrı ayrı analiz edilmiş, elde edilen bulgular Tablo 8'de verilmiştir.

Tablo 8. Deney ve Kontrol Grubundaki Ebeveynlerin Algıladıkları Yetersizlik Düzeyi Ön-test ve Son-test Puanlarına ilişkin Wilcoxon İşaretli Sıralar Testi Analiz Sonuçları

\begin{tabular}{|c|c|c|c|c|c|c|}
\hline Gruplar & Sontest-Öntest & $\mathrm{n}$ & Sıra Ortalamaları & Sıra Toplamı & Z & $\mathrm{p}$ \\
\hline \multirow{3}{*}{ Deney Grubu } & Negatif Sıra & 0 & .00 & .00 & \multirow{3}{*}{-2.375} & \multirow{3}{*}{$.01^{*}$} \\
\hline & Pozitif Sıra & 7 & 4.00 & 28.00 & & \\
\hline & Eşit & 1 & & & & \\
\hline \multirow{3}{*}{ Kontrol Grubu } & Negatif Sıra & 0 & .00 & .00 & \multirow{3}{*}{-1.342} & \multirow{3}{*}{.18} \\
\hline & Pozitif Sıra & 2 & 1.50 & 3.00 & & \\
\hline & Eşit & 6 & & & & \\
\hline
\end{tabular}

Tablo 8 incelendiğinde deney grubundaki ebeveynlerin ön-test ve son-test puanları arasında anlamlı bir farklılığın olduğu ( $Z=-2.375 ; p<.05)$, herhangi bir işlemin uygulanmadığı kontrol grubundaki ebeveynlerin ön-test ve son-test puanları arasında ise anlamlı bir farklılığın olmadığı $(Z=-1.342 ; p>.05)$ görülmüştür.

Bu sonuç ile deney grubundaki ebeveynlerin kendilerini bir ebeveyn olarak yeterli hissetme düzeyi ön-test puanlarının son-testte pozitif yönde artış göstermesi dikkate alındığında, uygulanan programın ebeveynlerin kendilerini yeterli hissetme düzeyleri üzerinde anlamlı bir etkisinin olduğu söylenebilir.

Deney grubundaki ebeveynlerin yetersizlik düzeyi son-test ve izleme testi ölçümlerinden aldıkları puanlar arasındaki farklılığı sınamak amacıyla yapılan Wilcoxon İşaretli Sıralar Testi analizinden elde edilen sonuçlar Tablo 9’ da yer almaktadır.

Tablo 9. Deney Grubundaki Ebeveynlerin Yetersizlik Düzeyi Son-test ve İzleme Testi Puanlarına İlişkin Wilcoxon İşaretli Sıralar Testi Analiz Sonuçları

\begin{tabular}{llcccc}
\hline Sontest-izleme & $\mathrm{n}$ & Sıra Ortalamaları & Sıra Toplamı & $\mathrm{Z}$ & $\mathrm{p}$ \\
\hline Negatif Sıra & 3 & 5.00 & 15.00 & & \\
Pozitif Sıra & 3 & 2.00 & 6.00 & -.954 & .34 \\
Eşit & 2 & & & & \\
\hline
\end{tabular}

Tablo 9 incelendiğinde deney grubuna katılan ebeveynlerin 'Yetersizlik Düzeyi' son-test ve izleme testi puanları arasında anlamlı bir farklılığın olmadığı $(Z=-.954 ; p>$.05) görülmektedir.

Denence 5: 'Şiddetsiz Karşı Koyma' programının uygulandığı deney grubu ebeveynlerinin kontrol grubu ebeveynlerine göre bir ebeveyn olarak algıladıkları destek düzeyi son-test puanları ön-test puanlarından anlamlı düzeyde yüksektir 
ve bu fark üç ay sonra yapılan izleme ölçümünde devam etmektedir.

Araştırmanın beşinci denencesini sınamaya yönelik verilerin analizi için parametrik olmayan testlerden biri olan Wilcoxon İşaretli Sıralar Testi uygulanmış, deney ve kontrol grubundaki ebeveynlerin ön-test ve son-test puanları arasında anlamlı bir farklılık olup olmadığına bakılmıştr. Analiz sürecinde deney ve kontrol grubuna ait veriler ayrı ayrı analiz edilmiş, elde edilen bulgulara Tablo 10'da yer verilmiştir.

Tablo 10. Deney ve Kontrol Grubundaki Ebeveynlerin Algıladıkları Destek Düzeyi Ön-test ve Son-test Puanlarına ilişkin Wilcoxon İşaretli Sıralar Testi Analiz Sonuçları

\begin{tabular}{|c|c|c|c|c|c|c|}
\hline Gruplar & Sontest-Öntest & $\mathrm{n}$ & Sıra Ortalamaları & Sıra Toplamı & Z & $p$ \\
\hline \multirow{3}{*}{ Deney Grubu } & Negatif Sıra & 0 & .00 & .00 & & \\
\hline & Pozitif Sıra & 7 & 4.00 & 28.00 & -2.392 & $.01^{*}$ \\
\hline & Eşit & 1 & & & & \\
\hline \multirow{3}{*}{ Kontrol Grubu } & Negatif Sıra & 1 & 1.00 & 1.00 & & \\
\hline & Pozitif Sıra & 2 & 2.50 & 5.00 & -1.069 & .28 \\
\hline & Eşit & 5 & & & & \\
\hline
\end{tabular}

Tablo 10 incelendiğinde deney grubundaki ebeveynlerin ön-test ve son-test puanları arasında anlamlı bir artış olduğu $(Z=-2.392 ; p<.05)$, herhangi bir işlemin uygulanmadığı kontrol grubundaki ebeveynlerin ön-test ve son-test puanları arasında ise anlamlı bir farklılı̆ın olmadığı $(Z=-1.069 ; p>.05)$ görülmüştür. Bu sonuç ile deney grubundaki ebeveynlerin algılamış oldukları destek düzeyi ön-test puanlarının son-testte pozitif yönde artş göstermesi dikkate alındığında, uygulanan programın ebeveynlerin algıladıkları destek düzeyleri üzerinde anlamlı bir etkisinin olduğu söylenebilir.

Deney grubundaki ebeveynlerin algıladıkları destek düzeyi son-test ve izleme testi ölçümlerinden aldıkları puanlar arasındaki farklılığı sınamak amacıyla yapılan Wilcoxon İşaretli Sıralar Testi analizinden elde edilen sonuçlar Tablo 11' de yer almaktadır.

Tablo 11. Deney Grubundaki Ebeveynlerin Algıladıkları Destek Düzeyi Ölçeği Son-test ve İzleme Testi Puanlarına ilişkin Wilcoxon İşaretli Sıralar Testi Analiz Sonuçları

\begin{tabular}{llcccc}
\hline Sontest-İzleme & $\mathrm{n}$ & Sıra Ortalamaları & Sıra Toplamı & $\mathrm{Z}$ & $\mathrm{p}$ \\
\hline Negatif Sıra & 2 & 2.00 & 4.00 & & \\
Pozitif Sıra & 2 & 3.00 & 6.00 & -.378 & .70 \\
Eşit & 4 & & & &
\end{tabular}

Tablo 11 incelendiğinde deney grubuna katılan ebeveynlerin algıladıkları destek düzeyi son-test ve izleme testi puanları arasında anlamlı bir farklılı̆ın olmadığı $(Z=-.378 ; p>.05)$ görülmektedir.

Kontrol grubundaki ebeveynlere herhangi bir deneysel işlem uygulanmadığından dolayı ADÖ, Anne Baba Stres Düzeyi Ölçeği, ebeveynlerin çocuklarında algıladıkları şiddet düzeyi, ebeveyn olarak kendilerinde algıladıkları yetersizlik ve destek düzeyi son-test ve izleme testi ölçümlerinden aldıkları puanlar arasındaki farklılığa bakılmasına gerek görülmemiştir.

\section{Tartışma, Sonuç ve Öneriler}

Bu araştırmada, şiddet davranışları olan çocuklara sahip ebeveynlere yönelik "Şiddetsiz Karşı Koyma" ebeveyn programı uygulanmıştı. Deneysel nitelikte yapılan bu çalışmada şiddet ve saldırganlık problemi, sadece bireyin yaşadığı bir sorun olarak değil, aynı zamanda bir aile ilişkileri, etkileşim biçimleri ve ailenin de içinde bulunduğu toplumsal ve kültürel bir yapı sorunu olarak ele alınmıştır. Araştırma sonuçları incelendiğinde, şiddetsiz karşı koyma ebeveyn programının uygulandığı deney grubu ebeveynlerinin, kontrol grubunda yer alan ebeveynlere kıyasla aile etkileşimi ve ilişkilerinin olumlu yönde geliştiği, çocuklarda görülen şiddet davranış oranının azaldığı, programa katılan ebeveynlerin yetersizlik, destek ve stres algıları üzerinde olumlu yönde ve anlamlı düzeyde etkiler olduğu bulunmuştur.

Araştırmanın sonuçları, yurt dışında ve Türkiye'de yapılan benzer bazı çalışmalarla paralellik göstermektedir. Omer, Schorr-Sapir ve Weinblatt (2008), tarafindan yapılan ve şiddete karşı direnmeyi amaçlayan bir çalışmada, programın ebeveyn ve çocuk arasındaki gerginliği azaltth̆ı ve mağdur olan kardeşlere koruma sağladığı bulunmuştur. Weinblatt ve Omer (2008), tarafindan yapılan bir başka çalışmada 41 aileye (73 anne-baba) beş haftalık bireysel seans ve telefon desteğini içeren NVR programı uygulanmıştr. Deney ve kontrol grupları üzerinde yapılan ölçümler sonrasında ebevey- 
nlerdeki izole olma, çaresizlik ve gerginliği artırıcı davranışların azaldığı, algılanmış sosyal desteğin arttğı ve ebeveynler tarafindan değerlendirilen deney grubundaki gençlerin dışa vuran şiddet davranışlarında anlamlı düzeyde azalma olduğu tespit edilmiştir. Lavi-Levavi, Shachar ve Ömer (2013) tarafindan yapılan çalışmada NVR eğitimine alınan ve yıkıcı davranışlara sahip çocukları olan ebeveynler kontrol grubu ile karşılaştırılmıştı. Her iki ebeveyn (anne ve baba) de ebeveynsel çaresizlik ölçümlerinde anlamlı iyileşmeler gösterse de babalar sadece üç ölçeğin (ebeveyn-çocuk gerginlik tırmanması, güç mücadeleleri ve ebeveynsel boyun eğme) ölçüm sonuçlarında anlamlı düzeyde iyileşme göstermişlerdir. Bir başka çalışmada, Oleffs ve diğerleri (2009), davranış problemleri olan 11-18 yaş aralığındaki 52 genç için plasebo ve kontrol gruplarını alt haftalık bireysel oturumları içeren NVR tedavisi ile karşılaştırılmıştır. NVR tedavi grubunda davranışsal dışa vuran semptomlarda ve ebeveynlerin başa çıkma becerilerinde anlamlı düzeyde gelişmeler olduğu görülmüştür. Lavi-Levavi ve diğerleri (2013) yaş ortalaması on iki olan ve davranış problemlerine sahip gençlerle 4-10 haftalık bireysel oturumlar ve telefon desteğini içeren kontrol gruplu deneysel çalışmasında, deney grubundaki ebeveynlerin çaresizlik duygularında belirgin azalma, gençlerle yapılan güç mücadelelerinde de azalma görülmüştür. Tedaviyi takiben izleme çalışmasında ebeveynler gençlere karşı daha az olumsuz duygular içinde olduklarını bildirmişlerdir. Van Holen ve diğerleri (2015) bakım evinde kalan ve davranış problemleri olan çocuklarla on haftalık oturumlar ve telefon desteğini içeren kontrol gruplu deneysel bir çalışma yürütmüşlerdir. Araştırmada NVR Modeli'nin, çocukların daha sağlıklı takibinin sağlanması ve daha fazla sosyal destek kullanımı ile diğer tedavi yaklaşımlarından anlamlı düzeyde farklı sonuçlar ortaya çıkartmıştır. Bu araştırmanın bulguları, farklı kültürlerde yapılan NVR uygulamalarının sonuçları ile benzer sonuçlar elde edildiğini göstemektedir.

Bununla birlikte, bu araştırmanın sonuçları, Türkiye'de lise öğrencilerinin ebeveynlerine yönelik Kılıçarslan (2016) tarafindan yapılan çalışma bulguları ile; çocuklarda görülen saldırgan davranışları azaltması, aile ilişkilerini geliştirmesi ve anne baba stres düzeylerini anlamlı derecede düşürmesi bakımından paralellik göstermektedir. Ebeveyn eğitimlerinin etkiliğine ilişkin Türkiye'de yapılan benzer çalışmalar incelendiğinde, farklı özelliklere sahip ailelere yönelik pek çok aile eğitimi programı uygulandığı görülmektedir. Uygulanan aile ve ebeveyn eğitim programları incelendiğinde ebeveynlerin çocuklarına yönelik tutum ve davranışlarının olumlu yönde değiştiği, özyeterlilik duygularının yükseldiği, ebeveynlikle ilgili stres düzeylerinin düştüğü, anne-baba-çocuk/ergen ilişkilerinin olumlu yönde değişim gösterdiği, ebeveyn ve çocuk arasındaki gerginliğin azaldığı, aile etkileşim tarzları ve üyeler arasındaki ilişkilerin farklılaştığı belirlenmiştir (Bal ve Bedel, 2015; Çekiç, 2015; Kaymak- Özmen, 2013; Kabasakal; 2013; Kocayürek ve Sümer, 2009; Yılmaz-Bolat, 2009; Akgün, 2008). Bu sonuçlar, bu araştırmanın bulguları ile paralellik göstermektedir.

Türkiye'de şiddet ve saldırganlık içeren davranışları azaltmayı amaçlayan çalışmalar çoğunlukla çocuklara ya da onların ebeveynlerine odaklanmaktadır. Şiddet gibi kültürel öğeleri de içinde barındıran ve tüm aile yapısını etkileyen köklü problemlerde ebeveyn ve onların çocuklarının sistem olarak birlikte ele alındığı programlara ihtiyaç olduğu düşünülmektedir. Bu araştırmada, Türk kültüründe yapılan deneysel çalışmalardan farklı olarak aileyi sistem çerçecesinde ele alan NVR Modeli uygulanmıştr. Aile etkileşimi ve işlevlerini temel alarak, çocuk ve ergenlerin saldırgan davranışlarını azaltmak amacıyla geliştirilen NVR Modeli, ülkemizde henüz yeterince tanınmamaktadır. Ailenin bir sistem olarak ele alındığı ve bu sistem içerisinde oluşan etkileşimin tüm aile bireylerinin tutum ve davranışlarını etkileyebileceği anlayışına dayalı olarak oluşturulan NVR Modeli'nin, Türkiye'deki ebeveyn-çocuk-öğretmen iletişimine farklı bir bakış açısı getirebileceği ve çocuklarda görülen saldırgan davranışlar ile baş etmede ebeveynlere ve okul ortamlarında çalışan öğretmen ve psikolojik danışmanlara katkı sağlayabileceği düşünülmektedir.

Şiddet ve saldırganlık gibi çok boyutlu bir problem ile baş etmede, çocuk ve ebeveynlerin yanı sıra, bütüncül bir anlayış çerçevesinde okullarda çalışan idareci ve öğretmenlerin de uygulanacak NVR programlarına dahil edilmesinin yararlı olabileceği düşünülmektedir. Bu kapsamda, programların özellikle okul ortamlarında görülmekte olan şiddet problemleri ile baş etmede öğretmenler, idareci ve okul psikolojik danışmanlarının işbirliğinde uygulanması, şiddet ve saldırganca davranışlarla baş etmek konusunda yetersizlik ve çaresizlik içerisinde olan eğitim personeli ve ebeveynlere yardımcı olabileceği düşünülmektedir. Bununla birlikte aile dışından da destek almanın önemini vurgulayan NVR ve benzeri programlar uygulanırken, Türk kültürü gibi kapalı ve toplulukçu geleneklerden gelen toplumlarda aile üyelerinin birbirlerine ve ev dışından başkalarına kendi duygularını daha rahat ifade etme ve destek istemek konusunda cesaretlendirilmeye intiyaçları bulunmaktadır (Kılıçarslan ve Erdem, 2017).

Bu çalışmanın sonuçları sınırlıkları ışı̆ında dikkatle değerlendirilmelidir. İlk olarak, çalışmanın kendisi tamamen kathlımcıların öz bildirim ölçümlerine dayanmaktadır. Bununla birlikte, bu araştırma sürecinde izleme aşaması öğrenilen becerilerin kalıcılığının değerlendirilmesi için kısadır, daha uzun sürelerde yeniden ölçümler yapılarak ebeveynlerden farklı zaman periyotlarında geribildirim alınabilir. Ek olarak çalışma grubu daha çok orta ve düşük sosyo-ekonomik sınıftan yetişkin ebeveynlerdir. Kısa süreli bu tür psikoeğitim programları nesiller arası aktarımların da etkisi olan ciddi çatışmaların var olduğu problemli ailelerde veya dezavantajlı sosyo-ekonomik arka plandan gelen ailelerde yetersiz ola-

| Kastamonu Eğitim Dergisi, 27(2), 2019| 
bilmektedir. NVR'yi bu tür ailelere uygulamak, yanı sıra ek müdahale desteklerini, takibi ve Türk kültür ve yaşantlarına adaptasyonu gerektirir. Bu çerçevede, NVR programının farklı popülasyon ve sosyo-ekonomik seviyelerden ebeveynlere, eğitimcilere ve bakım veren bireylere uygulanması ve etkililiğin değerlendirilmesi yararlı olabilir. Son olarak, bu araştırmada deney ve kontrol gruplarına katılan ebeveyn sayısı kısıtlıdır, bundan sonra yapılacak çalışmalarda babaların da sürece dahil edildiği, daha geniş katılımlı gruplar oluşturularak programın etkililiğinin genişleyebileceği düşünülmektedir.

\section{Kaynakça}

Akgün, E. (2008). Anne-Çocuk iliş̧isini oyunla geliştirme eğitiminin anne-çocuk etkileşim düzeyine etkisi. Yayımlanmamış Doktora Tezi, Ankara Üniversitesi Eğitim Bilimleri Enstitüsü, Ankara.

Alon, N. and Omer, H. (2006) The Psychology Of Demonization: Promoting Acceptance and Reducing Conflict. Mahwah, NJ: Lawrence Erlbaum Associates.

American Academy of Child and Adolescent Psychiatry (1997). Practice Parameters for The Forensıc Evaluation of Chıldren and Adolescents Who May Have Been Physically or Sexually Abused. Reprint requests to AACAP Publications Department, 3615 Wisconsin Ave., N.W., Washington, DC 20016.

Arkan, B.,\& Üstün, B. (2009). Davranım bozukluğu olan çocuklara psikiyatrik yaklaşımda anne-baba eğitim programları: İki örnek bağlamında bir değerlendirme. Psikiyatride Güncel Yaklaşımlar-Current Approaches In Psychıatry, 1, 155-174.

Bal, A. \& Bedel, A. (2015). The Effect of Family Counseling Training on the Relationship between Mother-Father and the Child. The Online Journal of Counseling and Education, 4(3), 1-14.

Bugental, D. B., Blue, J., \& Cruzcosa, M. (1989). Perceived control over caregiving outcomes: Implications for child abuse. Developmental Psychology, 25(4), 532-539.

Bugental D. B. \& Lewis J. C. (1998) Interpersonal power repair in response to threats to control from dependent others. In: Personal control in action: Cognitive and motivational mechanisms, ed. Kofta M., Weary G. \& Sedek G., pp. 341-62. Plenum.

Bulut, I. (1990). Aile değerlendirme ölçeği el kitabı. Ankara: Özgüzeliş Matbaası.

Buss, A.H., \& Perry, M. (1992). The Aggression Questionnaire. Journal of Personality and Social Psychology, 63, 452-459.

Corey, G. (2005). Psikolojik danışma, psikoterapi kuram ve uygulamaları. Ankara: Mentis Yayıncılık.

Cogan, D. (2014). Responding to child-to-parent violence: Innovative practices in child and adolescent mental health. Health \& Social Work, 39 (2), e1-e9.

Çekiç, A. (2015) Akılcı Duygusal Davranış̧̧ı Yaklaşıma Dayalı Olarak Geliştirilen Aile Eğitim Programının Anne Babaların Akılcı Olmayan İnançlarının ve Anne Babalık Streslerinin Azaltılması Üzerinde Etkililiği. Yayınlanmamış Doktora Tezi, Çukurova Üniversitesi, Adana.

Day, E.M. \& Heismann, E. (2010). Non-violent resistance programme: Guidelines for parents, care staff and volunteers working with adolescents with violent behaviours. Publisher: Pavilion Publishing (Brighton) Ltd.

Epli-Koç, H. (2013). Ergen-Ebeveyn Iliş̧ki Geliştirme Programının Ergenlerin Algıladıkları Ebeveyn Kabul/Red Düzeylerine ve Aile İ̧̧levlerine Etkisi, Yayımlanmamış Doktora Tezi. Ondokuz Mayıs Üniversitesi, Eğitim Bilimleri Enstitüsü, Samsun.

Golan, O., Shilo, H., \& Omer, H. (2016). Non-violent resistance parent training for the parents of young adults with high functioning autism spectrum disorder. Journal of Family Therapy. doi: 10.1111/1467-6427.12106.

Jakob, P. (2006). Bringing non-violent resistance to Britain. Context, 84, 36-38.

Haskan, Ö. \& Yıldııım, i. (2012). Şiddet Eğilimi Ölçeği'nin geliştirilmesi. Eğitim ve Bilim, 37 (163), 165-177.

Kabasakal, Z. (2013). The effects of mother education programs on the functionality, anger management and conflict solution levels of families. Eurasian Journal of Educational Research, 52, 1-20.

Kaymak-Özmen, S. (2013). Anne-baba eğitimi programının çocuklardaki davranış sorunları ve anne-babaların depresyon düzeylerine etkisi. Eğitim ve Bilim, 38(167), 98-113.

Kılıçarslan, S. (2016). Ergenlerde Görülen Saldırgan Davranışlarda Ebeveyn ve Ergenlere Uygulanan Psikoeğitim Programının Etkisinin Incelenmesi. Doktora Tezi, Çukurova Üniversitesi, Adana.

Kılıçarslan, S. \& Erdem, D. (2017). Ebeveynler İçin Yeni Bir Baş Etme Modeli: Yeni Otorite, Şiddetsiz Karşı Koyma. Mehmet Akif Ersoy Üniversitesi Eğitim Fakültesi Dergisi, 0 (44), 66-89. DOI: 10.21764/maeuefd.331990

Kocayürek, E, \& Sümer, H.Z. (2009). Baba Kathlım Eğitiminin Aile İşlevlerine ve Ergenlerin Akran Ilişsilerine Etkisi. Eğitimde Kuram ve Uygulama 2009; 5 (1): 3-17.

Kofta, G. Weary, \& G. Sedek (Eds.), Personal control in action: Cognitive and motivational mechanisms (pp. 341-362). New York: Plenum Press.

Lavi-Levavi, I., Shachar, I., \& Omer, H. (2013). Training in nonviolent resistance for parents of violent children: Differences between fathers and mothers. Journal of Systemic Therapies, 32(4), 79-93. 
Lebowitz, E. R. (2013). Parent-based treatment for childhood and adolescent OCD. Journal of Obsessive-Compulsive and Related Disorders. 2(4), 425-431.

Lebowitz, E. R., Dolberger, D., Nortov, E., \& Omer, H. (2012). Parent training in non violent resistance for adult entitled dependence. Family Process, 51(1), 1-17.

Lebowitz, E. R., Omer, H., Hermes, H., \& Scahill, L. (2014). Parent training for childhood anxiety disorders: The SPACE program. Cognitive and Behavioral Practice, 21(4), 456-469.

Lebowitz, E. R., Omer, H., \& Leckman, J. F. (2011). Coercive and disruptive behaviors in pediatric obsessive-compulsive disorder. Depression and Anxiety, 28(10), 899-905.

McCart, M.R., Priester, P. Davies, W.H., \& Azen, R. (2006) Differential effectiveness of behavioral parent-training and cognitive-behavioral therapy for antisocial youth: A meta-analysis. Journal of Abnormal Child Psychology,34(4), 525-541.

MacPhee D., Benson, J. B.,\& Bullock D. (1986). Influences on maternal self-perceptions. Paper presented at the Fifth Biennial International Conference on Infant Studies, Los Angles.

Newman, M., Fagan, C., \& Webb, R. (2014). Innovations in practice: The efficacy of nonviolent resistance groups in treating aggressive and controlling children and young people: A preliminary analysis of pilot NVR groups in Kent. Child and Adolescent Mental Health, 19(2), 138-141.

Omer, H., \& Weinblatt, U. (2008). Nonviolent resistance: a treatment for parents of children with acute behavior problems. Journal of Marital and Family Therapy 34(1):75-92.

Oleffs, B., von Schlippe, A., Omer, H., \& Kritz, J. (2009). Youngsters with externalizing behavior problems: Effects of parent-training. Familien dynamik, 34, 256-265.

Omer, H. (2004). Nonviolent resistance: A new approach to violent and self-destructive children. New York: Cambridge University Press.

Omer, H. (2011). The new authority: Family, school, community. New York: Cambridge University Press.

Omer, H. (2015). Vigilant care. Goettingen, Germany: Vandenhoeck \& Ruprecht.

Omer, H., \& Dolberger, D.I. (2015). Helping parents cope with suicide threats: An approach based on nonviolent resistance. Family Process.

Omer, H., Irbauch, R., Berger, H., \& Katz-Tissona, R. (2006). Non-violent resistance and school violence. Paper presented at the Mifgash Leavodah Hinukhit Sotzialit, Israel.

Omer, H., Steinmetz, S. G., Carthy, T., \& von Schlippe, A. (2013). The anchoring function: Parental authority and the parent-child bond. Family Process, 52(2), 193-206.

Onaylı, S. \& Erdur-Baker, Ö. (2013). Mother-Daughter Relationship's Links to Daughter's Self-Esteem and Life Satisfaction. Türk Psikolojik Danışma ve Rehberlik Dergisi. Cilt 4, Sayı 40, 167-175.

Patterson, G. R., \& Chamberlain, P. (1994). A functional analysis of resistance during parent training therapy. Clinical Psychology: Science and Practice, 1(1), 53-70.

Sharp, G. (1973). The politics of nonviolent action. Boston: Extending Horizons Books.

Sharp, G. (2005). Waging nonviolent struggle. Boston: Extending Horizons Books.

Schiff, N. P., \& Belson, R. (1988). The Gandhi technique: A new procedure for intractable problems. Journal of Marital and Family Therapy, 14, 261-266.

Schlippe, A. V. (2006). From family therapy to systemic parental coaching. In C. Tsirigotis, A. von Schlippe, \& J. Schweitzer-Rothers (Eds.), Coaching for parents: Mothers, fathers and their "job" (pp. 44-67). Heidelberg: Carl Auer (in German).

Şahin, F. \& Kalburan, N. (2009). Aile Eğitim Programları ve Etkililiği: Dünyada Neler Uygulanıyor? Pamukkale Üniversitesi Eğitim Fakültesi Dergisi Yıl 2009 (1) 25. Sayı 1.

van Holen, F., Vanderfaeillie, J., \& Omer, H. (2015). Adaptation and evaluation of a nonviolent resistance intervention for foster parents: A progress report. Journal of Marital and Family Therapy. 42(2): 256-271

Weinblatt, U., \& Omer, H. (2008). Non-violent resistance: A treatment for parents of children with acute behavior parents. Journal of Marital and Family Therapy, 34, 75-92.

Wilson, S. J.,\& Mark, W. L. (2007). Update of a meta-analysis of school-based intervention programs. American Journal of Preventive Medicine, 33(2),130-143.

Wilson, D \& Smith, M (2014) The unmet needs of the child in non-violent resistance: Integrating developmental-dyadic-psychotherapy approaches- lessons from working with adoptive families. Context- the Magazine for Family Therapy and Systemic Practice in the UK. Vol. 132, 22-26.

Worden, M. (2003). Family therapy basics. Brooks/Cole Publishing Company.

World Health Organization, (2002). World report on violence and health: Summary (WHO), Geneva.

Yılmaz- Bolat, E. (2009). Anne-baba eğitiminin beş-alt yaş çocuğa sahip anne babaların çocuk yetiştirme tutum ve davranışlarına etkisinin incelenmesi. Yayımlanmamış Doktora Tezi, Ankara Üniversitesi Fen Bilimleri Enstitüsü, Ankara. 